\title{
Microbiological, chemical, physical, and proteolytic activities of raw milk after thermal processing
}

\author{
[Atividade microbiológica, física, química e proteolítica do leite cru após o processamento térmico] \\ H.S. Milaneze ${ }^{1}$, L.S. Silva ${ }^{1}$, L.B.M. Kottwitz ${ }^{2}$, M.A. Zambom ${ }^{2}$, L.M. Fonseca ${ }^{3}$, \\ A.T.B. Guimarães ${ }^{2}$, M.S.S. Pozza ${ }^{4 *}$ \\ ${ }^{1}$ Aluno de pós-graduação - Universidade Estadual do Oeste do Paraná - Cascavel, PR \\ 2 Universidade Estadual do Oeste do Paraná - Cascavel, PR \\ ${ }^{3}$ Universidade Federal de Minas Gerais - Belo Horizonte, MG \\ ${ }^{4}$ Universidade Estadual de Maringá - Maringá, PR
}

\begin{abstract}
The aim was to evaluate the microbiological, chemical- physical, and shelf-life quality of milk samples after pasteurization (HTST) for 10 days or ultra-high temperature (UHT) treatment for 120 days. Raw milk counts of mesophilic aerobic microorganisms, Staphylococcus spp. and thermotolerant coliforms before HTST and UHT processing were 6.73 and $7.77 ; 2.84$ and 4.30 , and 4.68 and $4.37 \log _{10}$, respectively. Pseudomonas spp. were found in raw milk samples. No presence of any other microorganisms studied was detected and no microbial inhibitor was found. Processed samples met microbiological legal requirements. However, aerobic mesophilic counts for HTST pasteurized milk samples stored for 5 and 10 days increased to values comparable to those in raw milk. Composition chemical- physical of all samples were within legal limits. These results demonstrate that, although HTST and UHT processed milk comply with the microbiological standards required by Brazilian law, high microbial counts in raw milk are an issue, possibly due to failures in the early stages of the production chain. Increase in casein macropeptide (CMP), probably because of proteases psychrotrophic bacteria. It is concluded that the quality of raw milk directly influences the progressive increase of the CMP values.
\end{abstract}

Keywords: contamination, caseinomacropeptide, heat treatment

\section{RESUMO}

O objetivo da presente pesquisa foi avaliar a qualidade microbiológica, fisco-química e a vida de prateleira de amostras de leite, após o processo de pasteurização rápida (HTST) ou de ultra-alta temperatura (UHT) durante 10 dias, ou de ultra-alta temperatura (UHT) por 120 dias. As contagens de micro-organismos aeróbios mesófilos, Staphylococcus spp. e de coliformes termotolerantes do leite cru utilizado para tratamentos HTST e UHT foram, respectivamente ( $\left.\log _{10}\right)$ : 6,73 e 7,77; 2,84 e 4,30 e 4,68 e 4,37. Foi constatada a presença de Pseudomonas spp. no leite cru. Não foi detectada a presença de nenhum outro micro-organismo estudado, e as amostras estavam isentas de inibidores microbianos. Após a pasteurização, todas as amostras apresentaram contagens microbianas compatíveis com os limites legais. No entanto, as amostras de leite pasteurizado apresentaram contagens de aeróbios mesófilos semelhantes ao leite cru após cinco e 10 dias de armazenamento. A composição físico-química de todas as amostras estava de acordo com os limites legais. Observou-se acréscimo dos níveis de caseinomacropeptídeo (CMP) no leite UHT, provavelmente em função das proteases de bactérias psicrotróficas. Conclui-se que a qualidade do leite cru influencia diretamente os valores de CMP.

Palavras-chave: caseinomacropeptídeo, contaminação, tratamento térmico

Recebido em 14 de dezembro de 2016

Aceito em 8 de maio de 2018

* Autor para correspondência (corresponding author)

E-mail: msspozza@uem.br 


\section{INTRODUCTION}

The refrigerated storage of milk on farms is an important step in reducing the operational costs of production and avoiding loss of raw milk by acidification. However, longer periods of storage may result in decreased quality of milk derivatives due to the increased counts of psychrotrophic bacteria, such as Pseudomonas, and microbial enzymatic activity (Marchand et al., 2009; Machado et al., 2015).

In addition to milk spoilage microorganisms, there is also concern about bacteria associated with foodborne diseases (Claeys et al., 2013), including sporulated microrganisms such as Bacillus and Clostridium, which are also a risk to human health (Postollec et al., 2012; Claeys et al., 2013).

In the dairy industry, heating is used to ensure microbial safety of retail milk (Walstra et al., 2005), usually High Temperature and Short Time (HTST) pasteurization or Ultra High Temperature (UHT) processes. UHT technology offers the advantages of extended shelf-life of milk without need for refrigeration and avoiding significant changes in its essential characteristics and flavor (Walstra et al., 2005).

However, highly contaminated raw milk can result in reduced shelf-life of UHT milk (Barbano et al., 2006). Psychrotrophic bacteria may produce proteolytic and lipolytic enzymes that are directly related to loss of quality and reduced shelf-life of milk even after heat treatment, since such enzymes are highly heatresistant (Marchand et al., 2009; Samaržija et al., 2012; Von Neubeck et al., 2015). The result may be milk that is unstable to heat and undergoes physicochemical changes, such as coagulation during heating, gelation of UHT milk during storage, development of off-flavors and reduced cheese yield (Datta and Deeth, 2003; Svensson et al., 2004).

During cheese production, chymosin enzyme cleaves the 105-106 peptide bond of k-casein, releasing a 106-169 glycomacropeptide (GMP) (Sharma et al., 2013), also known as caseinomacropeptide (CMP). As a result, certain levels of CMP in milk may indicate a fraudulent addition of whey from cheese production or even deterioration due to a low quality product (Recio et al., 2000). Therefore, the objective of this study was to evaluate the microbiological quality of raw milk from two large dairies located in the western region of Paraná, Brazil, and the microbiological and physicochemical qualities and CMP levels during shelf-life of the milk after HTST and UHT treatment.

\section{MATERIALS AND METHODS}

The experiments were conducted at the State University of Western Paraná (PR), and CMP levels were quantified at the Federal University of Minas Gerais (MG). Milk samples were obtained from two large dairies in the cities of Toledo and Marechal Cândido Rondon, PR. The collection period was from October to December 2014, with four batches related to HTST treatment and three to UHT treatment, with a total of 49 samples.

Samples were collected from three collection points during processing: (1) raw milk pasteurizer sieve or initial storage silo valve, (2) pasteurized milk $\left(72\right.$ to $\left.75^{\circ} \mathrm{C}\right)$ valve after the holding tube section, and (3) bottled milk. At collection point 1 and 2, samples were collected in sterile bottles (approximately $80 \mathrm{~mL}$ volume) with three bottles at each collection point. Sampling at collection point 2 for both HTST and UHT milk took place after the holding tube, since this step is used in both treatments.

With collection point 3 (bottled milk), five samples were collected from each batch and stored according to specifications (refrigeration temperatures for HTST and UHT at room temperature and protected from sunlight). Each sample was opened for analysis at intervals according to the heat treatment. For HTST milk, analyses took place on the collection day (day 0) and after 3, 5, 7 and 10 days. For UHT milk, the asceptic containers were opened after $7,30,60$, 90 and 120 days of storage.

Microbiological analysis were performed on all samples of raw milk, fresh pasteurized milk and 3 storages times (days 0, 5 and 10 for pasteurized milk; days 7, 60 and 120 for UHT milk), thus representing initial, intermediate and final storage time. Microbial groups were analyzed: aerobic mesophilic, psychrotrophic, Staphylococcus spp, Bacillus cereus, Salmonella spp, sulphite-reducing Clostridium, fecal 
coliforms and Pseudomonas spp. (Silva et al., 1997; Brasil, 2003). Typical colonies of Salmonella spp were confirmed using kits for Enterobacteria - Newprov®. For Staphylococcus spp, all typical and atypical colonies were selected and counted, and then five colonies of each type were selected, seeded into tubes containing brain heart infusion (BHI) broth and then incubated at $36 \pm 1^{\circ} \mathrm{C}$ for 24 hours. Two tests were applied to the BHI broth, Gram staining and catalase testing (Silva et al., 1997; Brasil, 2003).

All samples of milk were screened for microbial inhibitors using a microbiological method (Tronco, 1997). The method consists of heating the sample at $80^{\circ} \mathrm{C}$ for $5 \mathrm{~min}$ and then cooling at $45^{\circ} \mathrm{C}$. Then $1 \mathrm{ml}$ of yoghurt solution $(10 \mathrm{ml}$ of yoghurt, $10 \mathrm{ml}$ of sterile water, $20 \mathrm{ml}$ of $0.34 \%$ bromocresol purple solution) was added and incubated at $45^{\circ} \mathrm{C}$ for $2 \mathrm{~h}$. The test was considered positive when the initial violet color showed no change and the sample remained liquid. Fat, protein, lactose and non-fat solids content and freezing points were determined using the Ultrasonic Milk Analyzer Master LM
(Milkotester $^{\circledR}$ ). Sediment mass was determined according to Silva (2003).

Proteolysis was estimated based on CMP levels using high-performance liquid chromatography (HPLC) with separation in a gel filtration column and ultraviolet (UV) detection (Brasil, 2006). Results were expressed in mg CMP per liter (mg/L).

Statistical analysis was descriptive and nonparametric using the Friedman test (XLSTAT $^{\circledR}$ 2015).

\section{RESULTS AND DISCUSSION}

The legal requirements for raw milk quality in Brazil (Brasil, 2011) specify $3.0 \times 10^{5} \mathrm{CFU} / \mathrm{mL}$ as the maximum count for mesophilic aerobic bacteria (equivalent to $5.48 \log _{10}$ ). Raw milk samples obtained in this study were noncompliant with the legislation; raw milk for both HTST and UHT treatment exceeded maximum limits with bacterial levels of 1.25 and $2.29 \log _{10}$, respectively (Table 1).

Table 1. Mean values for aerobic mesophilic count, total psychrotrophic, Staphylococcus spp., fecal coliforms, and Pseudomonas spp. in raw HTST and UHT milk during storage

\begin{tabular}{|c|c|c|c|c|c|c|c|c|c|}
\hline \multirow[t]{2}{*}{$\begin{array}{l}\text { Leite } \\
\text { HTST }\end{array}$} & \multicolumn{2}{|c|}{$\begin{array}{c}\text { Mesophilic } \\
\text { aerobic }\left(\log _{10}\right)\end{array}$} & \multicolumn{2}{|c|}{$\begin{array}{l}\text { Total } \\
\text { psychrotrophic } \\
\left(\log _{10}\right)\end{array}$} & \multicolumn{2}{|c|}{$\begin{array}{c}\text { Staphylococcus } \\
\text { spp. } \\
\left(\log _{10}\right)\end{array}$} & \multicolumn{2}{|c|}{$\begin{array}{l}\text { thermotolerant } \\
\text { coliforms }\left(\log _{10}\right)\end{array}$} & \multirow[t]{2}{*}{$\begin{array}{c}\text { Pseudomona } \\
s \\
\text { spp. } \\
\text { (present/abse } \\
\text { nt) } \\
\text { Result }\end{array}$} \\
\hline & A & SD & A & SD & A & SD & A & SD & \\
\hline Raw milk & $6.73^{b}$ & 6.79 & $7.63^{b}$ & 7.64 & $2.84^{\mathrm{a}}$ & 2.97 & $4.68^{\mathrm{b}}$ & 5.11 & Present \\
\hline $\begin{array}{c}\text { Pasteurizer } \\
*\end{array}$ & $3.56^{\mathrm{a}}$ & 3.40 & $1.27^{\mathrm{a}}$ & 1.22 & $1.51^{\mathrm{a}}$ & 1.69 & $<1.00^{\mathrm{a}}$ & 0.00 & Absent \\
\hline Day $0^{1}$ & $3.62^{\mathrm{a}}$ & 3.36 & $1.00^{\mathrm{a}}$ & 0.00 & $1.08^{\mathrm{a}}$ & 0.65 & $<1.00^{\mathrm{a}}$ & 0.00 & Absent \\
\hline 5 days $^{1}$ & $3.90^{\mathrm{ab}}$ & 3.92 & $2.98^{\mathrm{ab}}$ & 3.19 & $<1.00^{\mathrm{a}}$ & 0.00 & $<1.00^{\mathrm{a}}$ & 0.00 & Absent \\
\hline 10 days $^{1}$ & $4.94^{\mathrm{ab}}$ & 5.23 & $5.62^{\mathrm{ab}}$ & 6.04 & $<1.00^{\mathrm{a}}$ & 0.00 & $<1.00^{\mathrm{a}}$ & 0.00 & Absent \\
\hline UHT Milk & A & SD & A & SD & A & SD & A & SD & Result \\
\hline Raw milk & $7.77^{\mathrm{b}}$ & 7.93 & $7.82^{\mathrm{b}}$ & 7.66 & $4.30^{\mathrm{b}}$ & 4.22 & $4.37^{\mathrm{b}}$ & 4.76 & Present \\
\hline $\begin{array}{c}\text { Pasteurizer } \\
*\end{array}$ & $3.23 \mathrm{a}^{\mathrm{b}}$ & 3.17 & $<1.00^{\mathrm{a}}$ & 0.00 & $<1.00^{\mathrm{a}}$ & 0.00 & $<1.00^{\mathrm{a}}$ & 0.00 & Absent \\
\hline 7 days $^{2}$ & $<1.00^{\mathrm{a}}$ & 0.00 & $<1.00^{\mathrm{a}}$ & 0.00 & $<1.00^{\mathrm{a}}$ & 0.00 & $<1.00^{\mathrm{a}}$ & 0.00 & Absent \\
\hline 60 days $^{2}$ & $<1.00^{\mathrm{a}}$ & 0.00 & $<1.00^{\mathrm{a}}$ & 0.00 & $<1.00^{\mathrm{a}}$ & 0.00 & $<1.00^{\mathrm{a}}$ & 0.00 & Absent \\
\hline 120 days $^{2}$ & $<1.00^{\mathrm{a}}$ & 0.00 & $<1.00^{\mathrm{a}}$ & 0.00 & $<1.00^{\mathrm{a}}$ & 0.00 & $<1.00^{\mathrm{a}}$ & 0.00 & Absent \\
\hline
\end{tabular}

Averages followed by the same letter in the columns do not differ significantly by the Friedman test at $5 \%$ probability. ${ }^{*}$ Pasteurization at $75^{\circ} \mathrm{C}$ for 15 to 20 seconds. ${ }^{1}$ milk storage time after HTST treatment. ${ }^{2}$ milk storage time after UHT treatment. $\mathrm{A}=$ average; $\mathrm{SD}=$ standard deviation. 
The psychrotrophic bacteria are an important group of bacteria for the dairy industry, and Brazilian legal requirements specifies that this group should not exceed $10 \%$ of the total aerobic mesophilic population. Currently, this value is 4.48 $\log _{10}$, considering legal standards for mesophilic aerobic (Brasil, 2011). The samples analyzed in this study demonstrated a high quantity of psychrotrophic microorganisms in raw milk used for both dairy products, with average values of 7.63 and $7.82 \log _{10}$ in HTST and UHT milk, respectively. These values are of concern, since proteolysis in milk due to psychrotrophic bacteria may be noticeable when counts exceed $6.0 \log _{10}$ (Fox and McSweeney, 1998).

Pseudomonas spp. were detected in all samples of raw milk. These bacteria may cause gelation of UHT milk, as potentially occurs with $P$. fluorescens when present in large quantities $10^{7}$ to $10^{8} \mathrm{CFU} / \mathrm{mL}$. Staphylococcus spp. occurred in raw milk, with average values of 2.84 and $4.30 \log _{10}$ for HTST and UHT treatment, respectively. The presence of these microorganisms is attributed to the occurrence of mastitis in herds and unsatisfactory sanitary conditions at milking sites (Halasa et al., 2007; Bardiau et al., 2016). Counts of Staphylococcus spp. which exceed $5.00 \log _{10}$ are considered sufficient for the production of toxins levels which cause enterotoxemia in humans.

Fecal coliforms count reached 4.68 and $4.37 \log _{10}$ for raw milk used for HTST and UHT, respectively. In addition to their effect on milk quality, these microorganisms are of concern for human health, since some coliforms strains are pathogenic and can pose a danger to the population, as the case of some Escherichia coli (Claeys et al., 2013).

After the initial pasteurization $\left(72\right.$ to $\left.75^{\circ} \mathrm{C}\right)$ step, and as expected, the aerobic mesophilic counts in both dairy products showed a significant decrease compared to raw milk, with average values of 3.56 and $3.23 \log _{10}$ for HTST and UHT milk, respectively. All samples of HTST pasteurized milk were compliant with Brazilian legislation with regards to aerobic mesophilic counts, with a limit of $4.9 \log _{10}(8.0 \times$ $10^{4} \mathrm{CFU} / \mathrm{mL}$ ) (Brasil, 2011).
As shown in Table 1, all samples of UHT milk were in accordance with the Brazilian standard for aerobic mesophilic bacteria, that is counts of less than 100CFU/mL (Brazil, 1997). Counts were below $1.00 \log _{10}$ during the storage period (Table 1).

Aerobic mesophilic counts increased during the HTST milk shelf-life (days 5 and 10) to numbers similar $(\mathrm{P}>0.05)$ to the initial raw milk counts. However, these total aerobic mesophilic values were lower than the maximum stipulated by Normative Instruction 62 - IN 62 (Brasil, 2011). The gradual increase in microbial counts in stored HTST milk was expected, since pasteurization sterilization is not synonymous (Simon and Hansen, 2001; Claeys et al., 2013).

The pasteurization process significantly reduced the psychrotrophic bacteria count to average counts of 1.27 and $<1.00 \log _{10}$ for HTST and UHT milk, respectively. Since psychrotrophic bacteria counts in pasteurized milk should not exceed $3.90 \log _{10}$ (Brasil, 1952; 2011), all the samples were compliant for total psychrotrophic bacteria, except HTST milk stored for 10 days which averaged $5.62 \log _{10}$.

In the HTST milk, there was a gradual increase in total psychrotrophic bacteria during the storage period (Table 1), with counts after 5 and 10 days of storage which did not differ significantly from those of raw milk. Pseudomonas spp. was not found in the heattreated milk. Pasteurization resulted in a significant reduction of the Staphylococcus spp. population, as well the coliform count, which reached counts lower than $1.0 \log _{10}$.

Salmonella spp., sulphite-reducing Clostridium or Bacillus cereus spores were not found in any sample. Although there is allowance for limited counts of Bacillus cereus and sulphite-reducing Clostridium in raw milk, it is known that these two genera may be present in the sporulated form (Julien et al., 2008; Postollec et al., 2012) which are more heat-resistant. UHT treatment has a partial efficacy for the control of spores, an important aspect related to public health; together with the fact that heat-resistant enzymes can cause sensory changes in the final product (Claeys et al., 2013). 
Microbial inhibitors were not found in the milk samples (Brasil, 2011); this was demonstrated by the high microbial counts observed in raw milk (Table 1). Composition and freezing points of all samples were within legal limits (Table 2) (Brazil, 2011). The sedimentation rates for UHT milk were not held constant throughout the study period, with an increase in the sedimentation value observed over the course of time (Table 3 ).

Gelation can be a consequence of gradual loss of protein stability in milk that has been subjected to heat treatments. Stable colloidal particles, when heated, are disrupted by changes in electrostatic and spacial interactions which may affect the micelle integrity (Fox and McSweeney, 1998). Proteolysis of UHT milk reduces its stability which results in sediment formation and increase in viscosity of milk. This is an important quality issue (Recio et al., 2000; Datta and Deeth, 2003; Svensson et al., 2004).

One of the criteria that may be used to assess milk quality is the caseinomacropeptide index
(CMP), which reflects levels of proteolysis in the $\mathrm{k}$-casein fraction. Additionally, this index is used to detect addition of cheese whey to milk. All HTST samples had CMP index values within the limits set for the direct supply of milk, i.e., a maximum of $30 \mathrm{mg} / \mathrm{L}$ according to Brazilian requirements (Brasil, 2006) (Table 4). In addition, as shown in Table 4, there was no significant difference $(\mathrm{P}>0.05)$ between the average CMP values in raw milk and values during the shelf-life of pasteurized milk. The average CMP values for raw, pasteurized, and UHT milk after 7 days of storage (Table 4) were compliant with Brazilian legal requirements. However, UHT milk after 30 days of storage had a CMP value which exceeded $30 \mathrm{mg} / \mathrm{L}$. If this criterion was used as a quality indicator for processed milk, UHT milk after 30 days of storage it would be fit only for the production of milk products (30 to $75 \mathrm{mg} / \mathrm{L}$ ) (Brasil, 2006). After storage for 60 days (UHT), CMP values reached more than $75 \mathrm{mg} / \mathrm{L}$.

Table 2. Composition and freezing point of HTST and UHT milk during storage time

\begin{tabular}{|c|c|c|c|c|c|c|c|}
\hline \multicolumn{2}{|c|}{ HTST milk } & 0 days & 3 days & 5 days & 7 days & 10 days & Legal limits \\
\hline \multirow{2}{*}{ Fat $(\%)$} & $\mathrm{A}$ & 3.03 & 3.01 & 2.96 & 3.03 & 2.97 & \multirow{2}{*}{ Min. 3,0 } \\
\hline & SD & 0.39 & 0.38 & 0.38 & 0.39 & 0.34 & \\
\hline \multirow{2}{*}{ NFS (\%) } & A & 8.36 & 8.49 & 8.42 & 8.51 & 8.41 & \multirow{2}{*}{ Min. 8,4 } \\
\hline & SD & 0.36 & 0.12 & 0.12 & 0.16 & 0.16 & \\
\hline \multirow{2}{*}{ Protein $(\mathrm{g})$} & A & 3.26 & 3.31 & 3.28 & 3.32 & 3.28 & \multirow{2}{*}{ Min. 2,9 } \\
\hline & SD & 0.14 & 0,05 & 0.05 & 0.06 & 0.06 & \\
\hline \multirow{2}{*}{ Lactose $(\%)$} & A & 4.40 & 4.47 & 4.43 & 4.48 & 4.43 & \\
\hline & $\mathrm{SD}$ & 0.19 & 0.06 & 0.07 & 0.08 & 0.08 & \multirow{4}{*}{$\begin{array}{c}-0,512^{\circ} \mathrm{C} \mathrm{a}- \\
0,531^{\circ} \mathrm{C} \\
\text { Legal limits }\end{array}$} \\
\hline \multirow{2}{*}{$\mathrm{FP}\left({ }^{\circ} \mathrm{C}\right)$} & A & -0.509 & -0.518 & -0.512 & -0.518 & -0.512 & \\
\hline & SD & 0.023 & 0.007 & 0.008 & 0.011 & 0.010 & \\
\hline \multicolumn{2}{|c|}{ UHT milk } & 7 days & 30 days & 60 days & 90 dias & 120 dias & \\
\hline \multirow{2}{*}{ Fat $(\%)$} & A & 3.54 & 3.44 & 3.44 & 3.46 & 3.35 & \multirow{2}{*}{ Min. 3,0 } \\
\hline & SD & 0.11 & 0.28 & 0.07 & 0.13 & 0.15 & \\
\hline \multirow{2}{*}{ NFS (\%) } & A & 8.41 & 8.65 & 8.61 & 8.77 & 8.76 & \multirow{2}{*}{ Min. 8,4 } \\
\hline & SD & 0.27 & 0.24 & 0.22 & 0.32 & 0.25 & \\
\hline \multirow{2}{*}{ Protein $(\mathrm{g})$} & A & 3.20 & 3.25 & 3.23 & 3.29 & 3.29 & \multirow{2}{*}{ Min. 2,9 } \\
\hline & SD & 0.16 & 0.10 & 0.09 & 0.13 & 0.09 & \\
\hline \multirow{2}{*}{ Lactose $(\%)$} & A & 4.55 & 4.64 & 4.62 & 4.70 & 4.69 & \\
\hline & SD & 0.19 & 0.11 & 0.11 & 0,16 & 0.13 & \\
\hline \multirow{2}{*}{$\mathrm{FP}\left({ }^{\circ} \mathrm{C}\right)$} & A & -0.532 & -0.543 & -0.540 & -0.551 & -0.550 & \multirow{2}{*}{$\begin{array}{r}-0,527^{\circ} \mathrm{C} \mathrm{a}- \\
0,553^{\circ} \mathrm{C}^{*}\end{array}$} \\
\hline & SD & 0.023 & 0.014 & 0.015 & 0.021 & 0.016 & \\
\hline
\end{tabular}

$\mathrm{A}=$ average; $\mathrm{SD}=$ standard deviation; NFS -non-fat solids; FP $=$ Freezing point $\left({ }^{\circ}\right.$ Celsius $) ; *$ There isn`t currently legislation for UHT milk, but this value may be suggested as the standard for the freezing point of UHT milk (Beloti et al., 2015). 
Table 3. Gel formation (g / L) during UHT milk storage time

\begin{tabular}{ccc}
\hline storage time & sediment weight $(\mathrm{g} / \mathrm{L})$ & SD \\
\hline 7 days & $0,000^{\mathrm{a}}$ & 0.000 \\
30 days & $0,001^{\mathrm{a}}$ & 0.002 \\
60 days & $0,027^{\mathrm{a}}$ & 0.019 \\
90 days & $0,226^{\mathrm{a}}$ & 0.288 \\
120 days & $0,298^{\mathrm{a}}$ & 0.264 \\
\hline
\end{tabular}

Means followed by the same letter in the columns do not differ significantly by the Friedman test at 5\% probability. $\mathrm{SD}=$ standard deviation.

Table 4. Caseinomacropeptide levels (CMP) (mg/L) in raw, HTST and UHT milk during storage

\begin{tabular}{ccc}
\hline HTST milk & Average $(\mathrm{mg} / \mathrm{L})$ & SD \\
\hline Raw milk & $1.242^{\mathrm{a}}$ & 1.44 \\
Pasteurizer* $^{*}$ & $0.140^{\mathrm{a}}$ & 0.28 \\
0 days $^{1}$ & $2.368^{\mathrm{a}}$ & 4.12 \\
3 days $^{1}$ & $3.132^{\mathrm{a}}$ & 3.65 \\
5 days $^{1}$ & $2.724^{\mathrm{a}}$ & 3.17 \\
7 days $^{1}$ & $0.000^{\mathrm{a}}$ & 0.00 \\
10 days $^{1}$ & $0.000^{\mathrm{a}}$ & 0.00 \\
UHT Milk $^{\mathrm{a}}$ & Average $(\mathrm{mg} / \mathrm{L})$ & $\mathrm{SD}$ \\
Raw milk $^{\mathrm{a}}$ & $4.367^{\mathrm{ab}}$ & 4.42 \\
Pasteurizer* $^{*}$ & $2.414^{\mathrm{a}}$ & 3.90 \\
7 days $^{2}$ & $6.244^{\mathrm{ab}}$ & 5.43 \\
30 days $^{2}$ & $50.662^{\mathrm{ab}}$ & 6.00 \\
60 days $^{2}$ & $86.940^{\mathrm{ab}}$ & 11.31 \\
90 days $^{2}$ & $125.985^{\mathrm{ab}}$ & 9.91 \\
120 days $^{2}$ & $157.668^{\mathrm{b}}$ & 25.23 \\
\hline
\end{tabular}

Average followed by the same letter in the columns do not differ significantly by the Friedman test at $5 \%$ probability. Pasteurization at $75^{\circ} \mathrm{C}$ for 15 to 20 seconds. ${ }^{1}$ milk storage time after being subjected to HTST treatment. ${ }^{2}$ milk storage time after being subjected to UHT treatment. $\mathrm{SD}=$ standard deviation.

Even when counts of psychrotrophic bacteria in raw milk intended for HTST processing had reached values greater than $7.00 \log _{10}$ (Table 1), there was no increase in CMP values over the storage period. The CMP average values of stored UHT milk increased during the shelf-life, indicating possible action of thermal-resistant enzymes. In addition to quality problems in the UHT milk, this proteolytic action can result in false positive results for CMP analysis used to detect fraudulent addition of cheese whey to milk (Recio et al., 2000; Carvalho et al., 2007). This may be caused by psychrotrophic proteases which may hydrolyze k-casein in the bonds close to $105-106$, leading to the formation of a pseudoCMP.

\section{CONCLUSIONS}

The high bacteria count in raw milk suggests the need to adopt good manufacturing practices to prevent the initial contamination of raw milk, because, even if heat treatments prove effective in significantly reducing these microorganisms, progressive increase in CMP values for UHT milk were observed. Thermo-resistant proteolytic enzymes produced by psychrotrophic microorganisms can reduce the shelf-life of milk and its derivatives, in particular UHT milk. 


\section{REFERENCES}

BARBANO, D.M.; MA, Y.; SANTOS, M.V. Influence of raw milk quality on fluid milk shelf life1, 2. J. Dairy Sci., v.89, p.E15-E19, 2006.

BARDIAU, M.; CAPLIN, J.; DETILLEUX, J. Existence of two groups of Staphylococcus aureus strains isolated from bovine mastitis based on biofilm formation, intracellular survival, capsular profile and agr-typing. Vet. Microbiol., v.185, p.1-6, 2016.

BELOTI, V.; RIOS, E.A.; SILVA, M.R. et al. Determinação do parâmetro de crioscopia para leite UHT. Semin. Ciênc. Agrár., v.36, p.31813188, 2015.

BRASIL. Ministério da Agricultura, Pecuária e Abastecimento. Instrução Normativa $n^{\circ} 472$ 62, de 26 de agosto de 2003, oficializa os métodos analíticos oficiais para análises microbiológicas para controle de produtos de origem animal e água, com seus respectivos capítulos e anexos, em conformidade com o anexo desta instrução normativa, determinando que sejam utilizados no Sistema de Laboratório Animal do Departamento de Defesa Animal. Diário Oficial da União, Brasília, 2003.

BRASIL. Ministério da Agricultura, Pecuária e Abastecimento. Instrução normativa $n^{\circ}$ 69, de 13 de dez. de 2006, institui critério de avaliação da qualidade do leite in natura, concentrado e em pó, reconstituídos, com base no método analítico oficial físicoquímico denominado "Índice CMP". Diário Oficial da União, Brasília, 15 dez. 2006. Seção 1, p.7.

BRASIL. Ministério da Agricultura, Pecuária e Abastecimento. Instrução normativa $n^{\circ} 62$, de 29 de dez. de 2011, aprovar o regulamento técnico de produção, identidade e qualidade do leite tipo A, o regulamento técnico de identidade e qualidade de leite cru refrigerado, o regulamento técnico de identidade e qualidade de leite pasteurizado e o regulamento técnico da coleta de leite cru refrigerado e seu transporte a granel, em conformidade com os anexos desta Instrução Normativa. Diário Oficial da União, Brasília, 30 dez. 2011. Seção 1.
BRASIL. Ministério da Agricultura, Pecuária e Abastecimento. Portaria n ${ }^{\circ} 370$, de 04 de set. de 1997, aprova a inclusão do citrato de sódio no regulamento técnico para fixação de identidade e qualidade do leite UHT (UAT). Diário Oficial da União, Brasília, 8 ago.1997. Seção 1, p.19.

BRASIL. Regulamento de Inspeção Industrial e Sanitária de Produtos de Origem Animal (RIISPOA). Decreto $\mathrm{n}^{\circ} 30.691$ de 29 de março de 1952, alterado pelo Decreto $n^{\circ} 1.255$ de 25 de junho de 1962, estabelece as normas que regulam, em todo o território nacional, a inspeção e a fiscalização industrial e sanitária de produtos de origem animal, destinadas a preservar a inocuidade, a identidade, a qualidade e a integridade dos produtos e a saúde e os interesses do consumidor, executadas pelo Ministério da Agricultura, Pecuária e Abastecimento nos estabelecimentos registrados ou relacionados no Serviço de Inspeção Federal. Diário Oficial da União, Brasília, 7 jul. 1952.

CARVALHO, B.M.A.; CARVALHO, L.M.; ALCÂNTRA, L.A.P.; BONOMO, R.C.F. Métodos de detecção de fraude em leite por adição de soro de queijo. Rev. Electrón. Vet., v.8, p.1-7, 2007.

CLAEYS, W.L.; CARDOEN, S.; DAUBE, G. et al. Raw or heated cow milk consumption: review of risks and benefits. Food Control, v.31, p.251262, 2013.

DATTA, N.; DEETH, H.C. Diagnosing the cause of proteolysis in UHT milk. LWT-Food Sci. Technol., v.36, p.173-182, 2003.

FOX, P.F.; MCSWEENEY, P.L.H. Dairy chemistry and biochemistry. Massachusetts: Springer Science, 1998. 478p.

HALASA, T.; HUIJPS, K.; ØSTERÅS, O.; HOGEVEEN, H. Economic effects of bovine mastitis and mastitis management: a review. Vet. $Q .$, v.29, p.18-31, 2007.

JULIEN, M.C.; DION, P.; LAFRENIERE, C. et al. Sources of clostridia in raw milk on farms. Appl. Environ. Microbiol., v.74, p.6348-6357, 2008.

MACHADO, S.G.; SILVA, F.L.; BAZZOLLI, D. et al. Pseudomonas spp. and Serratia liquefaciens as predominant spoilers in cold raw milk. J. Food Sci., v.80, p.M1842-M1849, 2015. 
MARCHAND, S.; VANDRIESCHE, G.; COOREVITS, A. et al. Heterogeneity of heatresistant proteases from milk Pseudomonas species. Int. J. Food Microbiol., v.133, p.68-77, 2009.

POSTOLLEC, F.; MATHOT, A.G.; BERNARD, M. Tracking spore-forming bacteria in food: from natural biodiversity to selection by processes. Int. J. Food Microbiol., v.158, p.1-8, 2012.

RECIO, I.; GARCÍA-RISCO, M.R.; LÓPEZFANDIÑO, R. et al. Detection of rennet whey solids in UHT milk by capillary electrophoresis. Int. Dairy J., v.10, p.333-338, 2000.

SAMARŽIJA, D.; ZAMBERLIN, POGAČIĆ, T. Psychrotrophic bacteria and milk and dairy products quality. Mljekarstvo, v.62, p.77-95, 2012.

SHARMA, R.; RAJPUT, Y.S.; MANN, B. Chemical and functional properties of glycomacropeptide (GMP) and its role in the detection of cheese whey adulteration in milk: a review. Dairy Sci. Technol., v.93, p.21-43, 2013.

SILVA, N.V.C.A.; JUNQUEIRA, V.C.A.; SILVEIRA, N.F.A. et al. Manual de métodos de análise microbiológica de alimentos. São Paulo: Varela, 1997. 107p.
SILVA, P.H.F. Leite UHT: fatores determinantes para sedimentação e gelificação. 2003. 147f. Tese (Doutorado em Ciência dos Alimentos) - Universidade Federal de Lavras, Lavras, MG.

SIMON, M.; HANSEN, A.P. Effect of various dairy packaging materials on the shelf life and flavor of pasteurized milk. J. Dairy Sci., v.84, p.767-773, 2001.

SVENSSON, B.; EKELUND, K.; OGURA, H.; CHRISTIANSSON, A. Characterization of Bacillus cereus isolated from milk silo tanks at eight different dairy plants. Int. Dairy J., v.14, p.17-27, 2004.

TRONCO, V.M. Manual para inspeção da qualidade do leite. Santa Maria: UFSM, 1997. $166 \mathrm{p}$.

VON NEUBECK, M.; BAUR, C.; KREWINKEL, M. et al. Biodiversity of refrigerated raw milk microbiota and their enzymatic spoilage potential. Int. J. food Microbiol., v.211, p.57-65, 2015.

WALSTRA, P.; WALSTRA, P.; WOUTERS, J.T.; GEURTS, T.J. Dairy science and technology. [New Zealand]: CRC Press, 2005.808p. 